\title{
Phytochemical and Antimicrobial Studies on Acacia saligna Leaves
}

\author{
S.A. El-Toumy ${ }^{\#}$, J.Y. Salib, W.M. Mohamed and F.A. Morsy* \\ Chemistry of Tanning Materials and Leather Technology, \\ National Research Center and *Chemistry Department, \\ Faculty of Science, Helwan University, Cairo, Egypt.
}

\begin{abstract}
7 HE THERAPY of the medicinal plants has always been a part of our environment as they have several therapeutic virtues. These properties are generally attributed to secondary metabolites such as polyphenols. In this study we investigated the three extracts; ethyl acetate, methanolic and water extract of the leaves of Acacia saligna (Wendl H. L.) which is used traditionally in the treatment of various diseases. They were assayed against Gram-positive bacteria (Staphylococcus aureus, Staphylococcus pyogens, Bacillus cereus, Bacillus subtilis), Gram-negative bacteria (Escherichia coli), fungi and yeast (Candida albicans) using the diffusion and serial methods. The susceptibility of the microorganisms to the extracts of these plants was compared with each other and with selected antibiotics whereby the ethyl acetate extract being the most effective. The active ethyl acetate extract was phytochemicaly studied as well for their polyphenolic constituents, where they afforded sixteen polyphenolic compounds among which two different phenolic acids, two catechins and seven flavonoids were isolated for the first time from A. saligna. The structure of all the isolated compounds was elucidated on the basis of spectral analysis.
\end{abstract}

Keywords: Acacia saligna leaves, Fabaceae, Phenolic compounds and Antimicrobial assay.

Acacia is a genus of shrubs and trees of Gondwanian origin belonging to the Subfamily Mimosoideae of the Pea Family (Family Fabaceae), there are roughly 1300 species of Acacia worldwide, 13 species of Acacia in Egypt are known to grow wild in the Eastern Desert, Sinai Peninsula and the Oases of the Western Desert $^{(1)}$. A number of secondary metabolites have been reported from various Acacia species including hydrolyzable tannins, condensed tannins and flavonoids $^{(2)}$. In a review, discussed by Harborne and Williams ${ }^{(3)}$, many studies have suggested that flavonoids exhibit antioxidant, anti-inflamatory, antimicrobial, vascular activities and others medicinal properties.

The identification of Acacia species is difficult and their taxonomic relationships are not clear ${ }^{(4)}$ which led to lack of information given in the current literature about the phenolic constituents of the leaves of Acacia saligna and as many species of Acacia have been described to have astringent, aphroldisia,

\footnotetext{
${ }^{\#}$ Corresponding author: Email: Sayedeltomy @ yahoo.com
} 
antioxidant, antidiabetic, anti-ulcer and antisyphilic properties ${ }^{(5-8)}$, we therefore subjected this species for a comprehensive investigation due to its economic importance and the lack of literature concerning their constituents. Phytochemical investigation resulted in the isolation of gallic acid, methyl gallate, catechin, 7-Ogalloylcatechin, quercetin-3- $O-\alpha$-L-rhamnopyranoside, myricetin-3- $O-\alpha$-L-rhamnopyranoside, myricetin-3- $O-\alpha-\mathrm{L}$-arabinopyranoside, quercetin-3- $O-\alpha$-L-arabinopyranoside, myricetin-3-O- $\beta$-D-glucopyranoside, apigenin-7- $O-\beta$-D-glucopyranoside, luteolin- $7-$ $O$ - $\beta$-D-glucopyranoside, apigenin, luteolin, quercetin and myricetin from its ethyl acetate extract. The structure of the isolated compounds was elucidated on the basis of spectral analysis as UV, MS, ${ }^{1} \mathrm{H} \mathrm{NMR},{ }^{13} \mathrm{C}$ NMR.

\section{Experimental}

General

${ }^{1} \mathrm{H}$ and ${ }^{13} \mathrm{C}$ NMR: were measured relative to DMSO- $d_{6}$ at 500 and $75 \mathrm{MHz}$, respectively on Bruker AMS spectrometer-500 MHz where values are given in ppm; ESI-MS: on a Finnigan MAT 4600 spectrometer; UV: Shimadzu spectrophotometer model UV-240; CC: Polyamide 6S and Sephadex LH-20; PC: carried out on Whatman No.1 and 3MM using solvent systems (1) BAW (n-BuOH: HOAc: $\mathrm{H}_{2} \mathrm{O}, 4: 1: 5$, upper layer); (2) $\mathrm{H}_{2} \mathrm{O}$; (3) $15 \% \mathrm{AcOH}\left(\mathrm{AcOH}: \mathrm{H}_{2} \mathrm{O}\right)$.

\section{Plant material}

Acacia saligna leaves were collected from the Orman Botanical Garden, Giza, in September 2005. Identification of the plant was confirmed by the Department of Flora, Agricultural Museum, Ministry of Agriculture and Herbarium of the Department of Botany, Faculty of Science, Cairo University. Voucher specimen (number: As 30) was kept in Herbarium, National Research Centre, Cairo, Egypt.

\section{Extraction and isolation}

The comminuted air-dried leaves material $(1.5 \mathrm{~kg})$ was defatted with chloroform (2x3L) and exhaustively extracted with $\mathrm{MeOH}: \mathrm{H}_{2} \mathrm{O}$ (7:3) under reflux over a boiling water bath for $10 \mathrm{hr}$. The extract was then filtered and the solvent was removed in vacuo at $\approx 40^{\circ} \mathrm{C}$. The dried extract was then fractionated by successive maceration with ethyl acetate, methanol and water in a soxhlet extractor at room temperature till exhaustion (5L each). The extracts were concentrated to dryness under reduced pressure and controlled temperature $\approx 40^{\circ} \mathrm{C}$ to yield the crude extract of each. The respective yields of the ethyl acetate, methanol and water extracts (w/w) were found to be 150,75 and $100 \mathrm{~g}$, respectively.

A sample $(100 \mathrm{~g})$ of ethyl acetate extract was applied to the top of a column $(150 \times 3.5 \mathrm{~cm})$ containing $500 \mathrm{gm}$ of polyamide $6 \mathrm{~S}$. Gradient elution started with water followed by $\mathrm{H}_{2} \mathrm{O} / \mathrm{EtOH}$ mixtures of decreasing polarities at a flow rate $1 \mathrm{ml} /$ minute was then carried out. Eight fractions were then arised, individually collected, dried in vacuo at $\approx 40^{\circ} \mathrm{C}$ and subjected to detailed investigations. Application of $100 \mathrm{mg}$ of the material of fraction II to Sephadex LH-20 column Egypt. J. Chem. 53, No. 5 (2010) 
$(80 \times 1.5 \mathrm{~cm})$ and elution with $10 \%$ EtOH led to the desorption of two successive bands. These bands were concentrated to afford two pure samples of gallic acid $\left(\mathrm{A}_{1}\right)(27 \mathrm{mg})$ and methyl gallate $\left(\mathrm{A}_{2}\right)(30 \mathrm{mg}) .100 \mathrm{mg}$ of fraction III were carefully applied on a column $(80 \times 2 \mathrm{~cm})$ containing $\approx 60$ gm of Polyamide $6 \mathrm{~S}$. Elution with $50 \% \mathrm{EtOH}$ and inspection of the chromatographic process under UV light led to desorption of two bands which migrated successively along the column as fluorescent bands of characteristic color. Crystallization of the received crude samples of subfraction afforded a $25 \mathrm{mg}$ of catechin $\left(\mathrm{A}_{3}\right)$ and 29 $\mathrm{mg}$ of $7-O$-galloycatechin $\left(\mathrm{A}_{4}\right)$. The fraction IV $(170 \mathrm{mg})$ obtained after the evaporation of the eluent $(60 \% \mathrm{EtOH})$ was applied on a polyamide column and eluted by the solvent system n-Butanol-water saturated which gave rise to two successive sub-fractions. The first sub-fraction was further applied on smaller Sephadex LH-20 column and eluted by $40 \%$ EtOH to afford the purified samples of quercetin-3-O- $\alpha$-L-rhamnopyranoside $\left(\mathrm{A}_{5}\right)(30 \mathrm{mg})$ and myricetin-3- $O-\alpha-\mathrm{L}-$ rhamnopyranoside $\left(\mathrm{A}_{6}\right)(34 \mathrm{mg})$ while, the second sub-fraction, afforded a pure sample of myricetin-3-O- $\alpha$-L-arabinopyranoside $\left(\mathrm{A}_{7}\right)(28 \mathrm{mg})$. The column chromatography technique was applied for the resolution of $(142 \mathrm{mg})$ of the material of fraction $\mathrm{V}$. The process was carried out on polyamide column, using $\mathrm{n}$ Butanol-water saturated as the mobile phase led to the separation of two distinct sub-fractions of dark brown color under UV light, which were individually collected and dried under vacuo. The first sub-fraction afforded a pure sample of quercetin-3-O- $\beta$-D-glucopyranoside $\left(\mathrm{A}_{8}\right)(21 \mathrm{mg})$. Application of the obtained material of the second sub-fraction on Sephadex LH-20 column and eluted with $60 \% \mathrm{EtOH}$, led to the separation of pure samples of quercetin-3-O- $\alpha-\mathrm{L}-$ arabinopyranoside $\left(\mathrm{A}_{9}\right)(30 \mathrm{mg})$ and myricetin-3-O- $\beta$-D-glucopyranoside $\left(\mathrm{A}_{10}\right)(29$ $\mathrm{mg}) .90 \mathrm{mg}$ of fraction VI were applied on a Sephadex LH-20 $(60 \times 2 \mathrm{~cm})$ and eluted with $70 \% \mathrm{EtOH}$. Two successive major bands were individually desorbed from the column. Removal of the eluent in vacuo at $\approx 40^{\circ} \mathrm{C}$ and crystallization of the received dry material from $70 \% \mathrm{EtOH}$, gave pure samples of each of compounds; apigenin-7-O- $\beta$-D-glucopyranoside $\left(\mathrm{A}_{11}\right)(30 \mathrm{mg})$ and Luteolin-7-O- $\beta$ D-glucopyranoside $\left(\mathrm{A}_{12}\right)(27 \mathrm{mg})$. Sephadex LH-20 column chromatography of the material of fraction VII $(82.5 \mathrm{mg})$ using the solvent system n-BUOH-water saturated, was carried out whereby two major bands were detected under UV light. Both bands individually collected, dried and crystallized to give pure samples of apigenin $\left(\mathrm{A}_{13}\right)(30 \mathrm{mg})$ and Luteolin $\left(\mathrm{A}_{14}\right)(29 \mathrm{mg})$. Finally, a cellulose column chromatography of the material of fraction VIII $(97.5 \mathrm{mg})$ using ethanol as eluent, was carried out whereby two major bands were detected under UV light. Both bands were individually collected, dried and crystallized to give pure samples of quercetin $\left(A_{15}\right)(25 \mathrm{mg})$ and myricetin $\left(A_{16}\right)(23 \mathrm{mg})$.

\section{Characterisation of some natural compounds}

7-O-Galloyl-Catechin, $\left(\mathrm{A}_{4}\right)$

Colourless needles, m.p.: $165-168^{\circ} \mathrm{C} ; \mathrm{R}_{\mathrm{f}}$-values (x100): 53 (HOAc-15), 67 (BAW); UV $\lambda_{\max } \mathrm{nm}(\mathrm{MeOH}): 230 \mathrm{sh}, 278 ;{ }^{1} \mathrm{H}$ NMR $\delta$ (ppm): 7.27 (s, galloyl), $6.95\left(d, J=1.8 \mathrm{~Hz}, \mathrm{H}-2^{\prime}\right), 6.85\left(d, J=7.8 \mathrm{~Hz}, \mathrm{H}-5^{\prime}\right), 6.84(d d, J=7.8 \mathrm{~Hz}$, and $J=$ $\left.1.8 \mathrm{~Hz}, \mathrm{H}-6^{\prime}\right), 6.38(d, J=2.1 \mathrm{~Hz}, \mathrm{H}-6), 6.28(d, J=2.1 \mathrm{~Hz}, \mathrm{H}-8), 4.71(d, J=7.5$ $\mathrm{Hz}, \mathrm{H}-2), 3.02(m, \mathrm{H}-3), 2.70$ (eq., $d d, J=16.5 \mathrm{~Hz}$ and $J=8.1 \mathrm{~Hz}, \mathrm{H}-4)$ or 2.65 
(ax., $d d, J=16.5 \mathrm{~Hz}$ and $J=8.1 \mathrm{~Hz}, \mathrm{H}-4) ;{ }^{13} \mathrm{C}$ NMR $\delta$ (ppm): $82.21(\mathrm{C}-2), 67.23$ (C-3), 28.14 (C-4), 156.31 (C-5), 101.47 (C-6), 150.82 (C-7), 101.19 (C-8), 156.00 (C-9), 106.25 (C-10), 131.22 (C-1'), 114.53 (C-2'),145.15 (C-3'), 145.04 (C-4'), 115.13 (C-5'), 119.38 (C-5'), 120.43 (galloyl C-1), 109.68 (galloyl C-2), 145.59 (galloyl C-3), 138.76 (galloyl C-4), 145.59 (galloyl C-5), 109.68 (galloyl C-6), 164.63 (-COO-).

Quercetin-3-O- $\alpha$-L-rhamnopyranoside, $\left(A_{5}\right)$

$\mathrm{R}_{\mathrm{f}}$-values (x100):20 $\left(\mathrm{H}_{2} \mathrm{O}\right), 50$ (HOAc-15), 71 (BAW); UV $\lambda_{\max } \mathrm{nm}(\mathrm{MeOH})$ : 253, 263sh, 344; + NaOMe: 272, 322sh, 372; + NaOAc: 260, 300sh, 367; + $\mathrm{NaOAc} / \mathrm{H}_{3} \mathrm{BO}_{3}: 272,382 ;+\mathrm{AlCl}_{3}: 272,304$ sh, 333sh, 430; $+\mathrm{AlCl}_{3} / \mathrm{HCl}: 272$, 303sh, 353, 401; m.p.: $186^{\circ} \mathrm{C}$; Negative ESI-Mass: $[\mathrm{M}-\mathrm{H}]^{-} \mathrm{m} / \mathrm{z}$ 447.1; ${ }^{1} \mathrm{H}$ NMR: $\delta(\mathrm{ppm}) 7.33\left(d, J=2 \mathrm{~Hz}, \mathrm{H}-2^{\prime}\right), 7.28\left(d d, J=2 \mathrm{~Hz}\right.$, and $\left.J=8.5 \mathrm{~Hz}, \mathrm{H}-6^{\prime}\right), 6.90$ $\left(d, J=8.5 \mathrm{~Hz}, \mathrm{H}-5^{\prime}\right), 6.42(d, J=2 \mathrm{~Hz}, \mathrm{H}-8), 6.23(d, J=2 \mathrm{~Hz}, \mathrm{H}-6) ; 5.29(d, J=$ $1.41 \mathrm{~Hz}, \mathrm{H}-1$ " of rhamnose), 3.16-3.56 ( $m$, rest of rhamnose protons), $0.85(d, \mathrm{~J}=$ $6.07 \mathrm{~Hz}, \mathrm{CH}_{3}$ of rhamnose); ${ }^{13} \mathrm{C}$ NMR: $\delta(\mathrm{ppm}) 157.34(\mathrm{C}-2), 134.27$ (C-3), 177.79 (C-4), 161.35 (C-5), 98.78 (C-6), 164.34 (C-7), 93.70 (C-8), 156.86 (C9), 104.16 (C-10), 121.17 (C-1'), 115.52 (C-2'), 145.25 (C-3'), 148.50 (C-4'), 115.72 (C-5'), 120.80 (C-6'); 101.87 (C-1"), 70.43 (C-2"), 70.63 (C-3"), 71.25 (C4"), 70.11 (C-5"), 17.54 (C-6").

Myricetin-3-O- $\alpha$-L-rhamnopyranoside, $\left(A_{6}\right)$

$\mathrm{R}_{\mathrm{f}}$-values (x100) :15 ( $\left.\mathrm{H}_{2} \mathrm{O}\right), 45$ (HOAc-15), 72 (BAW); m.p.: 199-200 ${ }^{\circ} \mathrm{C}$; UV $\lambda_{\max } \mathrm{nm}(\mathrm{MeOH}): 250$ sh, 262, 298 sh, 349; + NaOMe: 272, 324, 392; + NaOAc : $270,318,366 ;+\mathrm{NaOAc} / \mathrm{H}_{3} \mathrm{BO}_{3}: 260,300,374 ;+\mathrm{AlCl}_{3}: 272,312,428 ;+$ $\mathrm{AlCl}_{3} / \mathrm{HCl}: 270,310,404$; Negative ESI-Mass: $[\mathrm{M}-\mathrm{H}]^{-}=\mathrm{m} / \mathrm{z} 463.1 ;{ }^{1} \mathrm{H}$ NMR: $\delta$ (ppm) $6.90\left(s, \mathrm{H}-2^{\prime}\right.$ and H-6'), $6.38(d, J=1.92 \mathrm{~Hz}, \mathrm{H}-8), 6.21(d, J=1.92 \mathrm{~Hz}$, H6); 5.21 ( $d, J=1.44 \mathrm{~Hz}, \mathrm{H}-1 "), 3.15-4.00$ ( $m$, protons of rhamnose), 0.85 ( $d, J=$ $6.15 \mathrm{~Hz}, \mathrm{CH}_{3}$-rhamnose); ${ }^{13} \mathrm{C}$ NMR: $\delta(\mathrm{ppm}) 157.49(\mathrm{C}-2), 134.29(\mathrm{C}-3), 177.91$ (C-4), 161.31 (C-5), 98.67 (C-6), 164.23 (C-7), 93.53 (C-8), 156.24 (C-9), 104.03 (C-10), 119.63 (C-1'), 107.92 (C-2'), 145.78 (C-3'), 136.46 (C-4'), 145.78 (C-5'), 107.92 (C-6'); 101.94 (C-1"), 70.40 (C-2"), 70.55 (C-3"), 71.29 (C-4"), $70.23(\mathrm{C}-5 "), 17.52$ (C-6").

Myricetin-3-O- $\alpha$-L-arabinopyranoside, $\left(A_{7}\right)$

$\mathrm{R}_{\mathrm{f}}$-values (x100): $07\left(\mathrm{H}_{2} \mathrm{O}\right), 24$ (HOAc-15), 64 (BAW); UV $\lambda_{\max }(\mathrm{nm})$ (MeOH): 265, 360; +NaOMe: 275, (dec.); +NaOAc: 270, 385; +NaOAc $/ \mathrm{H}_{3} \mathrm{BO}_{3}$ :

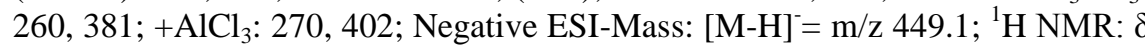
(ppm) $7.15\left(s, \mathrm{H}-2^{\prime}\right.$ and H-6'), $6.38(d, J=1.8 \mathrm{~Hz}, \mathrm{H}-8), 6.19(d, J=1.8 \mathrm{~Hz}, \mathrm{H}-$ 6); $5.26(d, J=5.13 \mathrm{~Hz}, \mathrm{H}-1 "$ of arabinose), 3.12-3.63 ( $m$, rest of arabinose protons); ${ }^{13} \mathrm{C}$ NMR: $\delta$ (ppm) 156.59 (C-2), 134.13 (C-3), 177.77 (C-4), 161.44 (C-5), 99.05 (C-6), 164.50 (C-7), 93.88 (C-8), 156.76 (C-9), 104.20 (C-10), 120.08 (C-1'), 108.74 (C-2'), 145.78 (C-3'), 137.09 (C-4'), 145.78 (C-5'), 108.74 (C-6'); 102.03 (C-1"), 72.13 (C-2"), 71.03 (C- 3"), 66.75 (C- 4"), 65.09 (C-5"). 
Quercetin-3-O- $\alpha$-L-arabinopyranoside, $\left(A_{9}\right)$

$\mathrm{R}_{\mathrm{f}}$-values (x100): $07\left(\mathrm{H}_{2} \mathrm{O}\right), 30$ (HOAc-15), 70 (BAW); m.p.: $218{ }^{\circ} \mathrm{C}$; UV $\lambda_{\max }(\mathrm{nm})(\mathrm{MeOH}): 260,300^{\mathrm{sh}}, 362 ;+\mathrm{NaOMe}: 277,333,412 ;+\mathrm{NaOAc}: 276$, 325,$388 ;+\mathrm{NaOAc} / \mathrm{H}_{3} \mathrm{BO}_{3}: 262,300 \mathrm{sh}, 382 ;+\mathrm{AlCl}_{3}: 276,303,338 \mathrm{sh}, 438$; + $\mathrm{AlCl}_{3} / \mathrm{HCl}:$ 276, 303sh, 367, 405; Negative FAB-Mass: $[\mathrm{M}-\mathrm{H}]^{-}=\mathrm{m} / \mathrm{z} 433 ;{ }^{1} \mathrm{H}$ NMR: $\delta(\mathrm{ppm}) 7.64\left(d, J=2.1 \mathrm{~Hz}, \mathrm{H}-2^{\prime}\right), 7.49(d d, J=2.1 \mathrm{~Hz}$ and $J=8.46 \mathrm{~Hz}$, H-6'), $6.82\left(d, J=8.46 \mathrm{~Hz}, \mathrm{H}-5{ }^{\prime}\right), 6.39(d, J=1.8 \mathrm{~Hz}, \mathrm{H}-8), 6.18(d, J=1.8 \mathrm{~Hz}$, $\mathrm{H}-6) ; 5.26(d, J=5.13 \mathrm{~Hz}, \mathrm{H}-1$ " of arabinose), 3.12-3.63 ( $m$, rest of arabinose protons); ${ }^{13} \mathrm{C}$ NMR: $\delta$ (ppm) 156.63 (C-2), 134.05 (C-3), 177.84 (C-4), 161.53 (C-5), 99.05 (C-6), 164.59 (C-7), 93.90 (C-8), 156.63 (C-9), 104.22 (C-10), 121.22 (C-1'), 115.71 (C-2'), 145.31 (C-3'), 148.94 (C-4'), 116.10 (C-5'), 122.36 (C-6'); 101.76 (C-1"), 71.07 (C-2"), 72.00 (C-3"), 66.46 (C-4"), 64.70 (C-5").

\section{Myricetin-3-O- $\beta$-D-glucopyranoside, $\left(A_{10}\right)$}

$\mathrm{R}_{\mathrm{f}}$-values (x100): $05\left(\mathrm{H}_{2} \mathrm{O}\right), 19$ (HOAc-15), 47 (BAW); UV $\lambda_{\max }(\mathrm{nm})$ $(\mathrm{MeOH}): 258,365$; + NaOMe: 266, 395; + NaOAc: 266, 340. (dec.); + $\mathrm{NaOAc} / \mathrm{H}_{3} \mathrm{BO}_{3}: 257,305 \mathrm{sh}, 395 ;+\mathrm{AlCl}_{3}: 269,310 \mathrm{sh}, 405 ;+\mathrm{AlCl}_{3} / \mathrm{HCl}: 270$, 360sh, 400; ${ }^{1} \mathrm{H}$ NMR: $\quad \delta(\mathrm{ppm}): 7.28\left(s, \mathrm{H}-2^{\prime}\right.$ and H-6'), $6.44(d, J=1.8 \mathrm{~Hz}, \mathrm{H}-8)$, $6.25(d, J=1.8 \mathrm{~Hz}, \mathrm{H}-6) ; 5.40(d, J=7.77 \mathrm{~Hz}, \mathrm{H}-1 "$ of glucose $), 3.36-3.73(\mathrm{~m}$, rest of glucose protons). ${ }^{13} \mathrm{C}-\mathrm{NMR} \delta(\mathrm{ppm}): 156.47(\mathrm{C}-2), 133.99(\mathrm{C}-3), 177.64$ (C-4), 161.44 (C-5), 98.91 (C-6), 164.36 (C-7), 93.62 (C-8), 156.36 (C-9), 104.14 (C-10), 120.23 (C-1'), 108.80 (C-2'), 145.58 (C-3'), 136.89 (C-4'), 145.58 (C-5'), $108.80(\mathrm{C}-6$ ').

\section{Antimicrobial activity assay}

Diffusion method

$0.1 \mathrm{ml}(10 \mathrm{mg})$ of samples extract was spotted on filter paper disc (whatman 3 $\mathrm{MM}, 8 \mathrm{~mm}$ diameter) and transferred to the surface of agar plates freshly inoculated with test organisms. The diameter of the clear zones of inhibition was determined after 24 and $48 \mathrm{hr}$ of incubation at $30^{\circ} \mathrm{C}$ for bacteria, yeast and fungi, respectively ${ }^{(9)}$. Disks $(8.0 \mathrm{~mm}$ in diameter) impregnated with each extract at a concentration of $10.0 \mathrm{mg} / \mathrm{ml}$ were placed on the inoculated plates. Similarly, each plate carried antibiotic disks ( $8.0 \mathrm{~mm}$ in diameter) of $20 \mathrm{mg} / \mathrm{ml} \mathrm{Ciprofl-oxacin}$ (for bacteria), and Fungican fluconazol (for fungi) were also used as positive controls.

\section{Serial dilution method}

Sets of test tubes, each containing $2 \mathrm{ml}$ of nutrient broth were prepared and sterilized. Twenty milligrams of plant extracts in $1 \mathrm{ml}$ sterilized water were aseptically transferred to the first tube and after thorough shaking; one $\mathrm{ml}$ of the mixture was aseptically transferred to a second tube. Such process was repeated from the second till the last tube of the series. Each tube was then inoculated with one drop of freshly prepared spoor suspension of the test organism and the whole series were incubated for $24 \mathrm{hr}$ for bacteria and $48 \mathrm{hr}$ for yeast and fungi at $30^{\circ} \mathrm{C}$.

The tubes showing no growth of the test organism (no turbid tubes) were counted and the minimum dilution of the fermented broth, which caused the 
inhibition of the test organism, was calculated ${ }^{(10)}$. All tests were performed in duplicate and the antimicrobial activity was expressed as the mean of inhibition zone diameters in $\mathrm{mm}$ produced by the sample.

\section{Determination of MIC}

Minimum inhibitory concentration (MIC) is defined as the lowest concentration of the antimicrobial agent in the liquid medium resulting in complete inhibition of visible growth. The lowest concentration of the tube or plate that did not show any visible growth by microscopic evaluation was considered as the MIC. Determination of MIC of samples was carried out by Serial dilution method ${ }^{(9)}$.

\section{Results and Discussion}

The Antimicrobial profile of Acacia saligna leaves occurred using the diffusion and serial methods whereby it indicated that the crude extracts containing most of polyphenols (ethyl acetate extract) has significant activity against various strains of bacteria (gram positive and gram negative), fungi and yeast.

Plant phenolics represent a huge number of natural compounds that are of great interest and importance nowadays due to their various pharmacological activities. The leaves of Acacia saligna were air-dried, grounded and the phenolic constituents were extracted with $70 \%$ aqueous methanol for several times. This crude extract was further fractionated using ethyl acetate, methanol and water.

As there are growing interests in using natural antimicrobial compounds, especially plant extracts ${ }^{(11)}$. The biological assay of the ethyl acetate extract (EA) together with the methanolic extract $(\mathrm{M})$ and water extract $(\mathrm{H})$ showed antimicrobial activity as shown in Table 1 whereby the Ciprofloxacin was used as antibiotic standard drug for bacteria and yeast while, fungican fluconazol was used as antibiotic standard for mould.

Among the three extracts, it was found that the ethyl acetate extract (EA) exhibited moderate activity against Staphylococcus aureus, Streptococcus pyogens and Bacillus cereus (20 mm diameter) and low activity against Bacillus subtilis (16 mm diameter) compared with that exerted by antibiotics (MIC, $1.020-3.05 \mathrm{mg} / \mathrm{ml}$ ), and it was found inactive against Bacillus subtilis. Besides, the three extracts exhibited an anti-candidal activity.

The antifungal activity of the three extracts was studied against seven pathogenic fungi. In contrast, the inhibition zones of the three extracts were almost zero or below $8 \mathrm{~mm}$, so that they were not active to all tested fungi microorganisms. Though no activity was observed against fungi, these results may provide scientific support for some uses of the plant in traditional medicine.

Egypt. J. Chem. 53, No. 5 (2010) 
TABLE 1. Antimicrobial activities ( $\mathrm{mm}$ in diameter) of samples against microbes by diffusion method.

\begin{tabular}{|c|c|c|c|c|}
\hline \multirow[t]{2}{*}{ Test organism } & \multicolumn{3}{|c|}{$\begin{array}{c}\begin{array}{c}\text { Zone of inhibition } \\
(\mathrm{mm} \text { diameter })\end{array} \\
\end{array}$} & \multirow{2}{*}{$\begin{array}{c}\text { Control } \\
\text { Antibiotic standard } \\
\text { (Ciprofloxacin) } \\
\text { (Fungican fluconazol) } \\
\text { 20mg/ml }\end{array}$} \\
\hline & $\begin{array}{c}\text { EA } \\
\text { ethyl } \\
\text { acetate } \\
\text { extract } \\
\end{array}$ & $\begin{array}{l}\text { M } \\
\text { Methyl } \\
\text { alcohol } \\
\text { extract } \\
\end{array}$ & $\begin{array}{c}\text { H } \\
\text { water } \\
\text { extract } \\
\text { (residue) } \\
\end{array}$ & \\
\hline $\begin{array}{l}\text { Gram-negative Bacteria } \\
1 \text { - Escherichia coli } \\
\text { (NRRLB-3704) }\end{array}$ & 0.0 & 0.0 & 0.0 & 40.0 \\
\hline Gram-positive Bacteria & & & & \\
\hline 1-Staphylococcus aureus & 15 & 0.0 & 0.0 & 44.0 \\
\hline 2-Streptococcus pyogens & 16 & 0.0 & 0.0 & 50.0 \\
\hline 3-Bacillus cereus & 16 & 0.0 & 0.0 & 36.0 \\
\hline $\begin{array}{l}\text { 4- Bacillus subtilis } \\
\text { (NRRLB-941) }\end{array}$ & 14 & 0.0 & 0.0 & 36.0 \\
\hline $\begin{array}{l}\text { Yeast } \\
\text { 1-Candida albicans } \\
(\text { NRRLY-12983) }\end{array}$ & 21 & 17 & 15 & 50.0 \\
\hline $\begin{array}{l}\text { 2-Sacchromyces cerevisiae } \\
\text { (NRRLY-12632) }\end{array}$ & \pm & \pm & 0.0 & 60.0 \\
\hline Fungi & & & & \\
\hline $\begin{array}{l}\text { 1- Aspergillus niger } \\
\text { ( NRRLA-326) }\end{array}$ & 0.0 & 0.0 & 0.0 & 30.0 \\
\hline $\begin{array}{l}\text { 2- Aspergillus flavos } \\
\text { (NRRLA-1957) }\end{array}$ & 0.0 & 0.0 & 0.0 & 36.0 \\
\hline $\begin{array}{l}\text { 3- Macrophomina Phaseali } \\
\text { (NRRLA-62743) }\end{array}$ & 0.0 & 0.0 & 0.0 & 35.0 \\
\hline $\begin{array}{l}\text { 4- Fusarium oxysporium } \\
\text { (NRRLA-2014) }\end{array}$ & 0.0 & 0.0 & 0.0 & 35.0 \\
\hline 5- Vas infectum & 0.0 & 0.0 & 0.0 & 30.0 \\
\hline 6- Diplodia oryzae & 0.0 & 0.0 & 0.0 & 40.0 \\
\hline $\begin{array}{l}\text { 7- Tricoderma viride } \\
\text { (NRRLA-63065) }\end{array}$ & 0.0 & 0.0 & 0.0 & 35.0 \\
\hline
\end{tabular}

Finally, MIC determination was carried out to calculate the lowest concentration of the antimicrobial agent for inhibition of different microbes, especially Staphylococcus aureus, Streptococcus pyogens, Bacillus cereus, Bacillus subtilis and Candida albicans. The MIC values of the two extracts (EA and $\mathrm{M}$ ) are generally within the range of $0.1-0.4 \mu \mathrm{g} / \mathrm{ml}$ against evaluated strains, as shown in Table 2. The ethyl acetate extract (1) was found to be more effective against Streptococcus pyogens and Candida albicans, MIC values of $0.41 \mu \mathrm{g} / \mathrm{ml}$ and $0.46 \mu \mathrm{g} / \mathrm{ml}$, respectively were attained.

For these reasons, the ethyl acetae extract was subjected to qualitative tests which indicated the presence of compounds of strong phenolic and flavonoid nature. 
TABLE 2. MIC (minimum inhibition concentration) of two extracts against different microbes.

\begin{tabular}{|l|c|c|}
\hline \multirow{2}{*}{ Test Organism } & \multicolumn{2}{|c|}{ MIC $(\boldsymbol{\mu g} / \mathbf{m l})$} \\
\cline { 2 - 3 } & Extract EA & Extract M \\
\hline Bacteria & 0.41 & - \\
1- Staphylococcus aureus & 0.46 & - \\
2- Streptococcus pyogens & 0.41 & - \\
3- Bacillus cereus & 0.14 & - \\
4- Bacillus subtilis ( NRRLB-941) & 3.7 & 0.41 \\
\hline Yeast & - & - \\
1- Candida albicans (NRRLY-12983) & & \\
2- Sacchromyces cerevisiae \\
$\quad$ (NRRLY-12632)
\end{tabular}

The phytochemical investigation of the ethyl acetate extract was then occurred by applying onto Polyamide 6S column chromatography and eluted with water and water/ethanol mixtures with gradual increase in concentration. A series of further fractionation on Sephadex LH-20 and polyamide 6S columns afforded the isolation of sixteen phenolic compounds. The structure of the isolated compounds was established through chromatography, as well as conventional chemical and spectroscopic methods of analysis (e.g. UV, ESI, 1/2 $\mathrm{D}$ NMR) where among them; catechin, 7-O-galloylcatechin, myricetin-3-O- $\alpha-\mathrm{L}-$ arabinopyranoside, quercetin-3-O- $\beta$-D-glucopyranoside, quercetin-3- $O-\alpha-\mathrm{L}$ arabinopyranoside, apigenin-7-O- $\beta$-D-glucopyranoside and luteolin-7- $O-\beta-\mathrm{D}$ glucopyranoside as shown in Fig. 1, were isolated for the first time from Acacia saligna leaves.

Compound $\left(\mathrm{A}_{4}\right)$ was strongly positive (a dark blue color) to the ferric chloride reagent and exhibited $R_{f}$-values and UV spectral data similar to those of Catechin derivatives. The ${ }^{1} \mathrm{H}-\mathrm{NMR}$ spectrum of $\left(\mathrm{A}_{4}\right)$ was similar to that of Catechin except for the additional signal at $\delta 7.27(2 \mathrm{H}, s)$, due to the presence of a galloyl group. The proton resonances of H-6 and H-8 appeared at $\delta 6.38$ and 6.28 ppm more downfield than observed in Catechin ${ }^{(12)}$, besides the ${ }^{13} \mathrm{C}$ NMR spectrum ensured esterification at position C-7 followed from the upfield shift of C-7 to $\delta 150.83$, while the recognizable downfield shift at C-6 and C-8 resonances to 101.47 and 101.19, respectively. Thus, compound $\left(\mathrm{A}_{4}\right)$ was identified as 7-O-GalloylCatechin $^{(13)}$. Compound $\left(\mathrm{A}_{5}\right)$ obtained as yellow amorphous powder of chromatographic properties and color reactions similar to those reported for quercetin 3-O-glycoside. This assumption was primarily supported by UV spectral data of $\left(\mathrm{A}_{5}\right)$ in methanol and different diagnostic shift reagents ${ }^{(14)}$. Complete acid hydrolysis of $\left(\mathrm{A}_{5}\right)$ yielded quercetin and rhamnose, identified by CoPC with authentic samples in different solvents. Compound $\left(\mathrm{A}_{5}\right)$ exhibited a Molecular weight of 448 in Negative ESI-MS spectrum analysis which showed $[\mathrm{M}-\mathrm{H}]^{-}$at $\mathrm{m} / \mathrm{z}$ : 447.1. Confirmation of the structure of $\left(\mathrm{A}_{5}\right)$ was achieved through ${ }^{1} \mathrm{H}$ NMR spectroscopic analysis whereby the spectrum revealed the characteristic

Egypt. J. Chem. 53, No. 5 (2010) 
pattern of quercetin proton resonances besides the anomeric proton resonance appearing as doublet signal of coupling constant $(J=1.41 \mathrm{~Hz})$, at $\delta 5.29 \mathrm{ppm}$ assignable to the rhamnoside proton $\mathrm{H}-1$ "; with the methyl rhamnose proton resonance revealed at $\delta 0.85 \mathrm{ppm}(d, J=6.07 \mathrm{~Hz})$. Finally, from the above data conpound $\left(\mathrm{A}_{5}\right)$ is quercetin $3-\mathrm{O} \alpha-\mathrm{L}$ rhamnopyranside.<smiles>Oc1cc(O)c2c(c1)O[C@H](c1ccc(O)c(O)c1)[C@H](O)C2</smiles>

$\mathbf{A}_{\mathbf{3}}: \quad \mathrm{R}=\mathrm{H}$

$\mathbf{A}_{4}: \quad \mathrm{R}=$

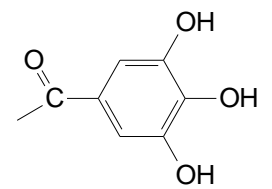<smiles></smiles>

$\mathbf{A}_{7}: \quad \mathrm{R}_{1}=O-\alpha$-L-arabinopyranoside; $\quad \mathrm{R}_{2}=\mathrm{H}$

$\mathbf{A}_{\mathbf{8}}: \quad \mathrm{R}_{1}=O$ - $\beta$-D-glucopyranoside; $\quad \mathrm{R}_{2}=\mathrm{H}$

$\mathbf{A}_{\mathbf{9}}$ : $\quad \mathrm{R}_{1}=O-\alpha$-L-arabinopyranoside; $\quad \mathrm{R}_{2}=\mathrm{H}$

$\mathbf{A}_{11}: \mathrm{R}_{1}=\mathrm{H} \quad \mathrm{R}_{2}=O$ - $\beta$-D-glucopyranoside;

$\mathbf{A}_{12}: \quad \mathrm{R}_{1}=\mathrm{H} \quad \mathrm{R}_{2}=O$ - $\beta$-D-glucopyranoside

$$
\begin{gathered}
\mathrm{R}_{3}=\mathrm{OH} ; \mathrm{R}_{4}=\mathrm{OH} \\
\mathrm{R}_{3}=\mathrm{OH} ; \mathrm{R}_{4}=\mathrm{H} \\
\mathrm{R}_{3}=\mathrm{OH} ; \mathrm{R}_{4}=\mathrm{H} \\
\mathrm{R}_{3}=\mathrm{R}_{4}=\mathrm{H} \\
\mathrm{R}_{3}=\mathrm{OH} ; \mathrm{R}_{4}=\mathrm{H}
\end{gathered}
$$

Fig. 1.

The pure yellow amorphous material of $\left(\mathrm{A}_{6}\right)$ showed chromatographic and UV spectral properties similar to those of myricetin 3-O-glycoside. Complete acid hydrolysis of $\left(\mathrm{A}_{6}\right)$ yielded myricetin and rhamnose, identified by $\mathrm{CoPC}$ with authentic samples in different solvents. Compound $\left(\mathrm{A}_{6}\right)$ exhibited a Molecular weight of 464 in Negative ESI-MS spectrum analysis which showed $[\mathrm{M}-\mathrm{H}]^{-}$at $\mathrm{m} / \mathrm{z}$ : 463.1. In order to determine the final structure of $\left(\mathrm{A}_{6}\right)$, it was subjected to ${ }^{1} \mathrm{H}$ NMR spectroscopic analysis. The proton resonances in the recorded spectrum $\left(\mathrm{DMSO}-d_{6}\right)$ revealed an anomeric proton resonance, appearing as doublet signal of coupling constant $(J=1.44 \mathrm{~Hz})$, at $\delta 5.21 \mathrm{ppm}$ assignable to the rhamnoside proton $\mathrm{H}-1$ ". While, the methyl rhamnose proton resonance revealed at $\delta 0.85$ ppm $(d, J=6.15 \mathrm{~Hz})$. Finally, the confirmation of the identity was achieved 
through ${ }^{13} \mathrm{C}$ NMR spectroscopic analysis which revealed the presence of a rhamnose moiety followed from the signal of the methyl carbon at $\delta 17.52 \mathrm{ppm}$. The signal of the C-3 carbon of the flavonol moiety at $\delta 134.29$ ppm showed the direct bonding between aglycone (myricetin) and sugar (rhamnose) moieties at the flavonol $\mathrm{C}-3$ position. Thus compound $\left(\mathrm{A}_{6}\right)$ was identified to be Myricetin-3$O$ - $\alpha$-L-rhamnopyranoside ${ }^{(15)}$. Also, compound $\left(\mathrm{A}_{7}\right)$ exhibited $\mathrm{R}_{\mathrm{f}}$-values and $\mathrm{UV}$ spectral data similar to those of myricetin 3-O-glycoside where complete acid hydrolysis of $\left(\mathrm{A}_{7}\right)$ yielded myricetin and arabinose which were identified by CoPC using authentic markers. This was supported by Negative ESI-MS analysis which revealed $[\mathrm{M}-\mathrm{H}]^{-}$peak at m/z: 449.1 as well as ${ }^{1} \mathrm{H}$ NMR spectrum which gave data identical to those reported for myricetin 3-arabinose ${ }^{(15)}$. The pyranose form of sugar arabinose showed a doublet signal of $\delta 5.26 \mathrm{ppm}$ of the anomeric sugar proton of coupling constant $5.13 \mathrm{~Hz}$. This analysis confirmed the characteristic pattern of myricetin, including $\delta 6.38 \mathrm{ppm}(d, J=1.8 \mathrm{~Hz})$ and $\delta 6.19$ $\operatorname{ppm}(d, J=1.8 \mathrm{~Hz})$ which correspond to $\mathrm{H}-8$ and $\mathrm{H}-6$ respectively. Finally compound $\left(\mathrm{A}_{7}\right)$ was identified to be Myricetin-3-O- $\alpha$-L-arabinopyranoside ${ }^{(15)}$.

Compound $\left(\mathrm{A}_{9}\right)$ appeared on PC as dark brown spot under UV light, turning yellow when fumed with ammonia vapor and bright yellow with $\mathrm{AlCl}_{3}$ reagent. $\left(\mathrm{A}_{9}\right)$ showed $\mathrm{R}_{\mathrm{f}}$-values and UV spectral data similar to those of quercetin 3glycoside ${ }^{(14)}$. Complete acid hydrolysis of $\left(\mathrm{A}_{9}\right)$ yield quercetin and arabinose which were identified by CoPC using authentic markers. This was supported by Negative FAB-MS analysis which revealed $[\mathrm{M}-\mathrm{H}]^{-}$ion peak at $\mathrm{m} / \mathrm{z}$ : 433. The structure was further confirmed through ${ }^{1} \mathrm{H}$ NMR spectrum which gave data identical to those reported for quercetin 3 -arabinoside ${ }^{(16)}$. The pyranose form of sugar arabinose showed a doublet signal of $\delta 5.26 \mathrm{ppm}$ of the anomeric sugar proton of coupling constant $5.13 \mathrm{~Hz}$. This analysis confirmed the characteristic pattern of quercetin, including $\delta 6.39 \mathrm{ppm}(d, J=1.86 \mathrm{~Hz})$ and $\delta 6.18 \mathrm{ppm}(d, J=1.83 \mathrm{~Hz})$ which correspond to H-8 and H-6 respectively. Final confirmation of compound $\left(\mathrm{A}_{9}\right)$ achieved by ${ }^{13} \mathrm{C}$ NMR, spectrum where the anomeric carbon of sugar appeared at $\delta$ $101.76 \mathrm{ppm}$ and the other sugar carbon signals appeared at their proper positions as reported for Quercetin-3-O- $\alpha$-L-arabinopyranoside.

The yellow amorphous powder of compound $\left(\mathrm{A}_{10}\right)$ was preliminary identified as a flavonol 3-glycoside; whose $\mathrm{R}_{\mathrm{f}}$-values and $\mathrm{UV}$ spectral data was similar to those reported for myricetin 3-O-glycoside ${ }^{(17)}$. Complete acid hydrolysis of $\left(\mathrm{A}_{10}\right)$ gave myricetin and glucose which were identified by CoPC using authentic markers. Both the ${ }^{1} \mathrm{H}$ NMR and ${ }^{13} \mathrm{C}$ NMR spectra confirmed the structure of $\left(\mathrm{A}_{10}\right)$ to be myricetin 3-O-glucoside, where the presence of $\beta$-glucopyranoside moiety in the compound of $\left(\mathrm{A}_{10}\right)$ followed from $\delta$ ppm of sugar at 5.40 ( $d, J=$ $7.77 \mathrm{~Hz}, \mathrm{H}-1$ " of glucose), 3.36-3.73 (m, rest of glucose protons) and the anomeric carbon resonance at $\delta 102.30 \mathrm{ppm}$. Resonances of the protons and carbons of the flavonoid moiety were assigned by comparison with the corresponding signals in the published spectrum of Myricetin-3-O- $\beta-\mathrm{D}$ glucopyranoside.

Egypt. J. Chem. 53, No. 5 (2010) 
We conclude from this study that, the chemical constituents of plant especially phenolic compounds, flavonoids and other compounds present in the plant may be involved in the observed antimicrobial effect of the plant's extract $^{(18,19)}$.

\section{References}

1. Tackhlom, V., Student's Flora of Egypt, Second edition, Cairo University, Cooperative Printing Company, Beirut (1974).

2. Seigler, D.S., Phytochemistry of Acacia-Sensu Lato. Biochemical Systematics and Ecology, 31, 845-873 (2003).

3. Harborne, J.B. and Williams, C.A., Advances in flavonoid research since 1992. Phytochemistry, 55, 481-504 (2000).

4. Maslin, B.R. and Stirton, C.H., Generic and infrageneric classification in Acacia (Leguminosae: Mimosoideae): A list of critical species on which to build a comparative data set. Bulletin International Group Study of Mimosoideae, 20, 22-44 (1997).

5. Kaur, K., Arora, S. and Hawthorne, M.E., A correlative study on antimutagenic and chemopreventive activity of Acacia auriculiformis A. Cunn and Acacia nilotica (L.) Willd.Ex.Del. Drug Chem. Toxicol. 25, 39-64 (2002).

6. Amos, S., Akah, P.A., Odukwe, C.J., Gamaniel, K.S. and Wambede, C., The pharmacological effects of an aqueous extract from Acacia nilotica seeds. Phytother. Res. 13, 683-685 (1999).

7. Wadood, A., Wadood, N. and Wahid, S.A., Effects of Acacia arabica and Caralluma edulis on blood glucose levels of normal and alloxan diabetic rabbits. J. Pak. Med. Assoc. 39, 208-212 (1989).

8. Saleem, A., Ahotupa, M. and Pihlaja, K., Total phenolics concentration and antioxidant potential of extracts of medicinal plants of Pakistan. Z. Naturforsch, 58c, 973-978 (2001).

9. Brown, D., Hitchcoch, M.J. and Katz, E., Purification and Characterization of kynurenine formamidase activities from streptomyces parvulus. Canadian Journal of Microbiology, 32, 465-472 (1980).

10. Egorov, N.S., Antibiotics a Scientific Approach. Mir Publishers. Moscow. Translated from Russian by Alexander Poshinkin (1985).

11. Cowan, M.M., Plant Products as Antimicrobial Agents. Clinical Microbiology Reviews, 12, 564-582 (1999).

12. Tanaka, T., Nonaka, G. and Nishioka, I., 7-O-Galloyl-(+)-Catechin and 3-Ogalloylprocyanidin B-3 from Sanguisorba Officinalis, Phytochemistry, 22, 2575-2578 (1983). 
13. El-Toumy S.A.A. and Mahdy, K.A., Polyphenols from Acacia nilotica leaves and evaluation of antihyperglycaemic effect of aqueous extract. Bull. Fac. Pharm, Cairo university, 42, 317-325 (2004).

14. Mabry, T.J., Markham, K.R. and Thomas, M.B., The Systematic Identification of Flavonoids, Springer-verlag, Berlin (1970).

15. Ye, G. and Huang, C., Flavonoids of Limonium aureum. Chemistry of Natural Compounds, 42, 232-234 (2006).

16. Vvedenskaya, I.O., Rosen, T., Guido, J.E., Russell, D.J., Mills, K.A. and Vorsa, N., Characterization of flavonols in cranberry (Vaccinium macrocarpon) powder. $J$. Agric. Food Chem., 52, 188 - 195 (2004).

17. Markham, K.R., Techniques of Flavonoid Identification, Academic Press, London (1982).

18. Zhu, X., Zhang, H. and Lo, R., Phenolic compounds from the leaf extract of artichoke (Cynara scolymus L.) and their antimicrobial activities. J. Agric. Food Chem. 52, 7272-7278 (2004).

19. Chacha, M., Bojase-Moleta, G. and Majinda, R.R., Antimicrobial and radical scavenging flavonoids from the stem wood of Erythrina lattissima. Phytochemistry, 66, 99-104 (2005). 


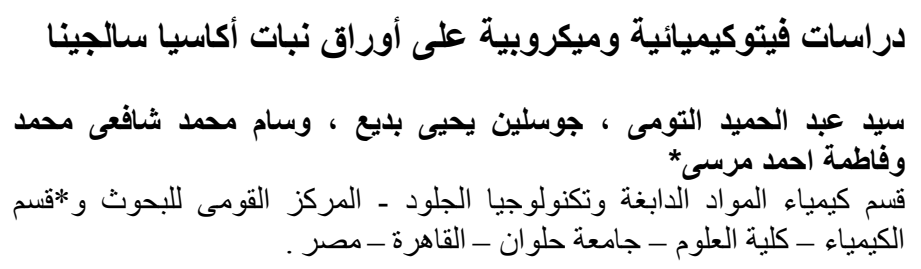

تهذف هذه الدراسة الى التعرف على المكونات الكيميائية وخاصة عديدة الفينول

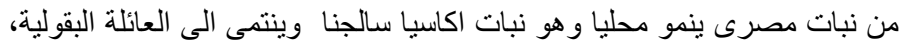

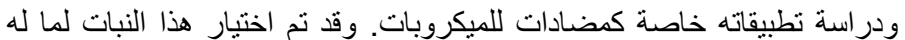

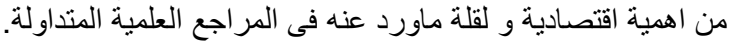

تم تجميع الاوراق وتجفيفها وطحنها حيث تم استخلاص المكونات الفينولية

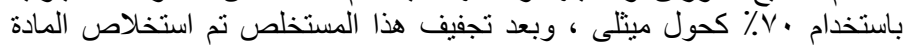

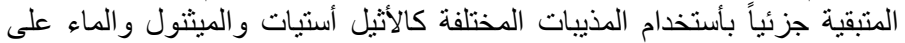

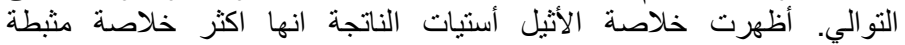

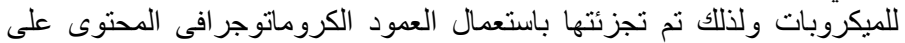

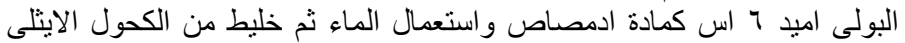

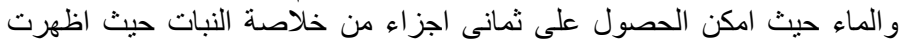

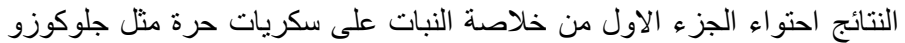

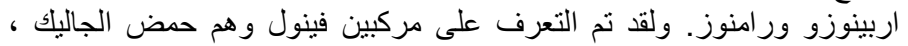

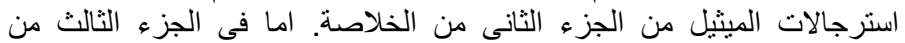

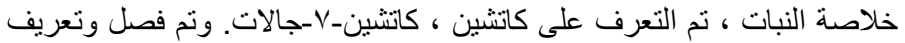

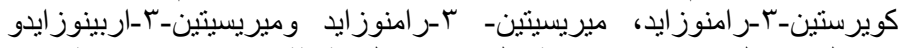

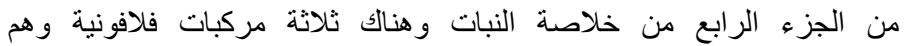

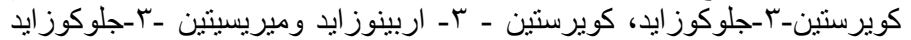

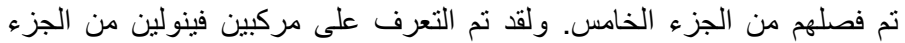

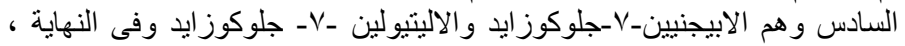

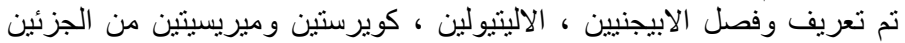
السابع و الثامن من الخلاصنة.

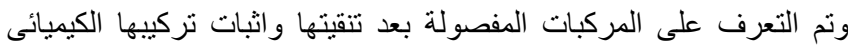

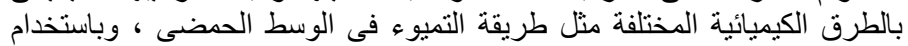

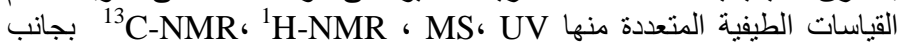
الخو اص الكروماتوجر افية.

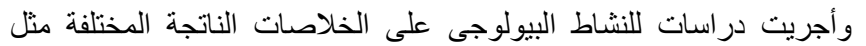

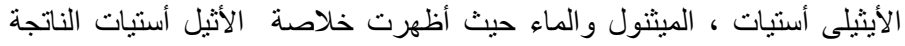
انها اكثر خلاصة مثبطة للميكروبات. المبات 